\title{
SPEECH ACTS IN THE VIDEO SCRIPT \\ OF AN ATHEIST CONVERTING TO ISLAM \\ BY LAMPU ISLAM YOUTUBE CHANNEL
}

\author{
Amelia Balqis Siregar, Efendi Barus \\ Faculty of Literature, Universitas Islam Sumatera Utara \\ Medan, Indonesia \\ e-mail: balqissboregg@gmail.com
}

Received: 2021-10-19

Accepted: 2021-11-21

\begin{abstract}
This research was conducted to examine speech act in the video script of Lampu Islam Youtube Channel. The edition of the video is entitled An Atheist Converting to Islam. This study aims to answer the problem about the classification of speech act found in the video script. This research applied the theory of speech act proposed by Austin and further developed by Searle. There are three types of speech act. The classification involves locutionary, illocutionary and perlocutionary acts. The result of the research shows that all the type of Speech Act can be found in the video script. The utterances which belong to locutionary act reach four (4) occurrences. For illocutionary, there are two (2) utterances. Then, the utterances of perlocutionary acts occur most dominantly with sixteen (16) occurrences. Perlocutionary act reaches $62.5 \%$ occurrences in the video script. From the analysis, it can be concluded that the script is intended to give an effect to the listeners of the channel and to offer ideas to other people.
\end{abstract}

Keywords: pragmatic, speech act, locutionary, illocutionary, perlocutionary.

\section{Introduction}

Language is a system of conventional spoken, manual (signed), or written symbols by means of which human beings, as members of a social group and participants in its culture, express themselves. Henry Sweetan, English phonetician and language scholar, stated that language is the expression of ideas by means of speechsounds combined into words. Words are combined into sentences. This combination answers that of ideas into thoughts.

Language interacts with every aspect of human life in society. It can be understood only if it is considered in relation to society. Language can be used in a speech or utterance. The study of language is called linguistics. Pragmatics is a part of linguistics. Pragmatics is related to speech acts, where pragmatic is the study of language and its users, while speech act is the study of speech and action.

Based on the topic of the paper it is concerned with speech acts viewed from video script of lampu Islam youtube channel an atheist converting to Islam. This topic will be elaborated according to the theory given by Austin and Searle, but the writer will stress on the theory given by Searle (1979), because he has developed his theory more than Austin's. 
Austin (1975) is the first person who introduces speech act and divides speech act into three classification such as locutionary act, illocutionary act, and perlocutionary act. And then Searle (1979) develops illocutionary act into five classification, such as representatives, directives, commisives, expressives, and declaratives. Finally, the theory proposed by Austin dan developed by Searle is applied in this study.

This video is a video featuring a speech from a speaker about his journey to Islam. This study is purposed to understand the meaning contained in the utterances that are described by the speaker in the video trough the classification of speech act.

\section{Literature Review}

\subsection{Speech Act}

Speech-act theory was introduced in 1975 by Oxford philosopher J.L Austin in How to Do Things With Words and further developed in 1976 by American philosopher J.R. Searle. It considers three levels or components of utterances: locutionary acts (the making of a meaningful statement, saying something that a hearer understands), illocutionary acts (saying something with a purpose, such as to inform), and perlocutionary acts (saying something that causes someone or the hearer to act or give response).

Speech acts are acts that refer to the action performed by producing utterances. People can perform an action by saying something. A Definition of Speech acts is an action that performs through language is called as speech acts. Austin (1975) defines speech act as the actions performed in saying something physical action merely through words and phrases. Aitchison (2003: 106) defines speech acts as a number of utterance behave somewhat like actions. It is important to know the relationship between utterance and meaning. Speech acts are something expressed by an individual that not only presents information but performs an action as well. This analysis is important to make the readers know how words or expressions coorperate with act. Speech act is a subfield of pragmatic, which Pragmatics is the study of context, or more precisely, a study of the way context can influence our understanding of linguistic utterances.

Any speech acts is really the performance of several acts at once, distinguished by different aspects of the speaker's intention: there is the act of saying something, what one does in saying it, such as requesting or promising, and how one is trying to affect one's audience". Speech acts serve their function once they are said or communicated. These are commonly taken to include acts such as apologizing, promising, ordering, answering, requesting, complaining, warning, inviting, refusing, and congratulating.

Speech acts, a variety of verbal communication and also a subdivision of pragmatics, often takes place in verbal and nonverbal communication. Yule (1996) states that speech acts are a study of how the speakers and hearers use language. Bach and Harnish (1979) explains that an action in verbal communication has message in itself, so the communication is not only about language but also with action. There are certain aims beyond the words or phrases when a speaker says something. Austin (in Tsui, 1994: 4) explains that speech acts are acts that refer to the action performed by produced utterances. In line with this, Yule (1996: 47) states that speech acts is action which is performed via utterances. Stating the same idea, Birner (2013) also says that uttering something means doing something. The conveyed utterances are paramount to the actions performed. In conclusion speech act is the utterance that occurs and act refers to an action. 


\subsection{Classification of Speech Act}

There are three types of acts in the speech acts according to Austin, they are locutionary, illocutionary, and perlocutionary.

\section{a. Locutionary Act}

Traditional sense (Austin, 1975: 108). In line with this, Cutting (2002: 16) states that locutionary act is what is said. Also proposed by Yule (1996) who states that locutionary act is the act of producing meaningful utterances. The example of the locutionary speech act can be seen in the following sentences:

1. It's so dark in this room.

2. The box is heavy.

The above two sentences represent the actual condition. The first sentence refers to the lighting of the room and the second sentence refers to the weight of the box.

\section{b. Illocutionary Act}

The illocutionary act is performed via the communicative force of an utterance, such as promising, apologizing, offering (Yule, 1996:48). This act is also called the act of doing something in saying something. The most significant level of action in a speech act is the illocutionary act because the force, which has been desired by the speakers, determines this act. Illocutionary act can be the real description of interaction condition. For example:

1. It's so dark in this room.

2. The box is heavy.

Based on the examples above, the first sentence shows a request to switch the light on and the second sentence shows a request to lift up the box. Further, Austin (1962: 150-151) classifies illocutionary acts into five major classes as follows:

a. Verdictives are typified by the giving of verdict, as the name implies, by a jury, arbitrator, or umpire. However, they need not be final; they are, for example, an estimation, reckoning, or appraisal. It is essential to give a finding to somethingfact or value-, which is for different reasons hard to be certain about.

b. Exercitives are exercise of power, right, or influence. The examples are appointing, voting, ordering, urging, advising, and warning.

c. Commisives are typified by promising or otherwise undertaking. They commit the hearer to do something, but include also declaration or announcements of intention, which are not promise, and also rather vague things, which can be called espousal, as for example siding with.

d. Behabitives are very miscellaneous group and have to do with attitudes and social behavior. The examples are apologizing, congratulating, condoling, cursing, and challenging.

e. Expositives are difficult to define. They make plain how utterances fit into the course of an argument or conversation, how words are use, or in general are expository. The examples are „I reply”, „I assume”.

Searle (1979) classified types of illocutionary act into five, they are representatives, directives, commissives, declarative, and expressive. 
a. Representatives are speech acts that the utterances commit the speaker to the truth of the expressed proposition. The utterances are produced based on the speaker's observation of certain things then followed by stating the fact or opinion based on the observation. When someone says "she's beautiful", the speaker can state the sentence based on the fact or just give his or her own opinion about physical condition of a person. It also states what the speaker believes to be the case or not. Statements of fact, assertions, conclusions, and descriptions are all examples of the speaker representing the world as he or she believes it is. For example when someone says "The earth is flat", it represents the speaker's assertions about the earth. The speaker has opinion that the earth is flat. Representatives speech act can be noted by some speech acts verb, such as: remind, tell, assert, deny, correct, state, guess, predict, report, describe, inform, insist, assure, agree, claim, beliefs, conclude. Representatives mean the speaker in uttering a representation converge his believe that some propositions are true. Example: the sun shines on the east. Representatives are speech acts that the utterances commit the speaker to the truth of the expressed proposition. The utterances are produced based on the speaker's observation of certain things then followed by stating the fact or opinion based on the observation. It also states what the speaker believes to be the case or not. Statements of fact, assertions, conclusions, and descriptions are all examples.

b. Directives are a speech acts that speaker uses to get someone else to do something. These speech acts include requesting, questioning, command, orders, and suggesting. For example, when someone says "Could you lend me a pencil, please?" the utterance represents the speaker requests that the hearer to do something which is to lend him a pencil.

c. Commissives are speech acts that the utterances commit the speaker to some future course of action, these include promising, threatening, offering, refusal, pledges. For example when someone says "I'll be back", represents the speaker's promise that he/she will be back.

d. Expressives are speech acts that the utterances express a psychological state. These speech acts include thanking, apologizing, welcoming, and congratulating. For example, when someone says "don't be shy, my home is your home." Or "how big this mosque!" The utterance represents the speaker's expression that he/she welcomes someone.

e. Declaratives are speech acts that the utterances effect immediate changes in the institutional state of affairs and which tend to rely on elaborate exta- linguistic institutions. These speech acts include excommunicating, declaring war, christening, firing from employment. For example, "you are dead to me."

\section{c. Perlocutionary Act}

Hufford and Heasley (1983:250) states that perlocutionary act is the act that is carried out by a speaker when making an utterance causes in certain effect on the hearer and others. Perlocutionary act is also the act offering someone. Perlocutionary act refers to the effect the utterance has on the thoughts or actions of the other person. A perlocutionary act is specific to the circumstances of issuance, and is therefore not conventionally achieved just by uttering that particular utterance, and includes all those effects, intended or unintended, often indeterminate, that some particular utterance in a particular situation cause. For example:

1. It is so dark in this room. 
2. The box is heavy

Based on the example it can be inferred that the first sentence is uttered by someone while switching the light on and the second sentence is done by someone while lifting up the box.

On the other hand, speech acts may have relationship with Pragmatics, why? Because pragmatics is subfield of speech acts and also the study of meanings based on the context and the meaning is not structural meaning but what the speaker means or based on the situation or condition where the speaker used the language.

\subsection{Relationship between Pragmatics and Speech Act}

Speech act theory is a subfield of pragmatics that studies how words are used not only to present information but also to carry out actions. Many philosophers and linguists study speech act theory as a way to better understand human communication. Speech act is a part of pragmatics where there are certain aims beyond the words or phrases when a speaker says something. Speech acts are acts that refer to the action performed by produced utterances. Through speech acts, the speaker can convey physical action merely through words and phrases. Pragmatics is the study of meanings in relation to speech situation. The specific relationship between speech acts and pragmatics is related to language contextually, and aims to understand the intent of the utterances spoken through actions that can influence others.

\subsection{Context of Situation}

A situational context or context of situation is an important element in communication. As stated by Leech (1983: 13), context has a great influence and also effect in understanding the meaning of an utterance. Through the context, the speaker and the addressee share their background in understanding the utterances. Malinowski (in Halliday and Hasan, 1986: 6) defines context of situation as the environment of the text that includes the verbal and the situational environment in which the text is uttered. Holmes (2001: 8) explains that there are some components, in any situation, will be generally reflected by the linguistic choices. They are the participant, the setting or social context of interaction, the topic, and the last is the function.

\section{Research Method}

The method in this research is qualitative research. Qualitative research is a scientific method of observation to gather non-numerical data while focusing on meaning-making. Qualitative research approaches are viewed from pragmatic meaning about speech act. This is a social phenomenon in the form of linguistics.

Qualitative research is also used to uncover trends in thought and opinions, and dive deeper into the problem. Shank (2002) defines qualitative research as "a form of systematic empirical inquiry into meaning".

\section{Discussion}

\subsection{Classification of Speech Act}

The data is taken from the Video Script of Lampu Islam Youtube Channel entitled An Atheist Converting to Islam. The video used as the material for analysis is a video featuring a speech from a speaker who tells his journey to know Islam. This area of study is concerned with the ways in which can be used not only to present 
Speech Acts in The Video Script of An Atheist Converting to Islam by Lampu Islam Youtube Channel, Amelia Balqis Siregar, Efendi Barus

information but also to carry out actions. It is used in linguistics, philosophy, psychology, legal and literary theories, and even the development of artificial intelligence.

The following data show the utterances found in the script. The three types of Speech Act can be seen from the script. Below is the expression of speech act taken from the video script:

Table 1. Classification of Speech Act Found in the Video Script

\begin{tabular}{|c|c|c|c|c|}
\hline \multirow[b]{2}{*}{ No. } & \multirow[b]{2}{*}{ Utterance } & \multicolumn{3}{|c|}{ Classification of Speech Act } \\
\hline & & $\begin{array}{c}\text { Locutionary } \\
\text { Act }\end{array}$ & $\begin{array}{c}\text { Illocutionary } \\
\text { Act }\end{array}$ & $\begin{array}{c}\text { Perlocutionary } \\
\text { Act }\end{array}$ \\
\hline 1. & $\begin{array}{l}\text { Naturally as an aussie, the } \\
\text { first thing I did was to } \\
\text { investigate Christianity. }\end{array}$ & & & State \\
\hline 2. & $\begin{array}{l}\text { I said "you could have even } \\
\text { chosen a lion's head or } \\
\text { something a bit better?"' }\end{array}$ & & & Offer \\
\hline 3. & $\begin{array}{l}\text { And I found that I wasn't into } \\
\text { making a leap of faith, I } \\
\text { wanted proof. }\end{array}$ & & & Ask/Request \\
\hline 4. & $\begin{array}{l}\text { And they seemed to be living } \\
\text { one with the world and that's } \\
\text { what really appealed to me. }\end{array}$ & & & Suggest \\
\hline 5. & $\begin{array}{l}\text { As Aussie, I don't want to } \\
\text { offend any Australians here, } \\
\text { but my upbringing is from my } \\
\text { country upbringing. }\end{array}$ & State & & \\
\hline 6. & $\begin{array}{l}\text { They would pick up the } \\
\text { Quran and they would say } \\
\text { "read this bro, and there was } \\
\text { the answer" }\end{array}$ & & & Inform \\
\hline 7. & $\begin{array}{l}\text { I said to one of the brothers } \\
\text { "'what's your opinion on the } \\
\text { matter? Why don't you give } \\
\text { your opinion?", }\end{array}$ & & & Complain \\
\hline 8. & $\begin{array}{l}\text { I said "Allah, this is my } \\
\text { moment. This is the time im } \\
\text { about to jump into Islam. All } \\
\text { I need is just a sign. Just a } \\
\text { little sign". }\end{array}$ & & & Ask \\
\hline 9. & $\begin{array}{l}\text { Absolutely nothing happened. } \\
\text { I was really disappointed. }\end{array}$ & & & Complain \\
\hline 10. & $\begin{array}{l}\text { The fact that we have this } \\
\text { world, the fact there is this } \\
\text { creation, these are the signs } \\
\text { for all of us. }\end{array}$ & & Inform & \\
\hline 11. & $\begin{array}{l}\text { The next day I decided this is } \\
\text { it, im becoming a muslim. }\end{array}$ & State & & \\
\hline 12. & I thought Subhanallah look at & & Inform & \\
\hline
\end{tabular}




\begin{tabular}{|c|l|l|l|l|}
\hline & $\begin{array}{l}\text { this religion, look at how } \\
\text { stronghly are! }\end{array}$ & & Admit \\
\hline 13. & $\begin{array}{l}\text { But, they realized that this } \\
\text { religion was actually making } \\
\text { me a better person. }\end{array}$ & & & \\
\hline 14. & $\begin{array}{l}\text { Alhamdulillah ever since then } \\
\text { I look as good as I do now. }\end{array}$ & Gateful & & \\
\hline 15. & $\begin{array}{l}\text { You've been a better person, } \\
\text { you're been a muslim. }\end{array}$ & State & & Persuade \\
\hline 16. & $\begin{array}{l}\text { Sure, Islam is good religion, } \\
\text { so make me a better person. }\end{array}$ & & & \\
\hline
\end{tabular}

From the table above, the explanation of the expression can be put as follows: State

State is something to express definitely or clearly in speech or writing. This expressions below are the examples:

\section{Perlocutionary Act:}

Naturally as an aussie, the first thing I did was to investigate Christianity.

$\rightarrow$ It means that the speaker state himself to investigate christianity as an aussie.

But, they realized that this religion was actually making me a better person.

$\rightarrow$ It means that the speaker states others appraisal to himself.

Locutionary Act:

"'The next day I decided this is it, I'm becoming a muslim."

$\rightarrow$ It means that the speaker states his decision becoming a muslim.

"'As Aussie, I don't want to offend any Australians here, but my upbringing is from my country upbringing. "

$\rightarrow$ It means that the speaker talks about his upbringing from his country.

'You've been a better person, you're been a muslim."'

$\rightarrow$ It means that the speaker states his appraisal based on what he knows.

\section{Offer}

Offer is present or proffer (something) for (someone) to accept or reject as so desired. This expression can be described by the utterance such as:

\section{Perlocutionary Act:}

I said: you could have even chosen a lion's head or something a bit better?

$\rightarrow$ It means that the speaker offers something better to the hearer.

\section{Ask or Request}

Ask or Request is to speak or write to someone saying that you want them to do something, to give you something, or to allow you to do something. Say something in order to obtain an answer or some information. Or an act of asking for something, or the thing asked for. This expression is exemplified with the following utterances:

Perlocutionary Act:

And I found that I wasn't into making a leap of faith, I wanted proof.

$\rightarrow$ It means that the speaker asks or requests what he wants.

I said 'Allah, this is my moment. This is the time im about to jump into Islam. All I need is just a sign. Just a little sign".

$\rightarrow$ It means that the speaker asks something he needs. 
Speech Acts in The Video Script of An Atheist Converting to Islam by Lampu Islam Youtube Channel, Amelia Balqis Siregar, Efendi Barus

\section{Inform}

Inform is giving someone facts or important information or to tell someone about something. This expression describes the utterances below:

\section{Illocutionary Act:}

The fact that we have this world, the fact there is this creation, these are the signs for all of us.

$\rightarrow$ It means that the speaker tells about the important information based on true fact.

I thought Subhanallah look at this religion, look at how stronghly are!

$\rightarrow$ It means that the speaker informs that how stronghly the religion are.

\section{Perlocutionary Act:}

They would pick up the Quran and they would say "read this bro, and there was the answer"

$\rightarrow$ It means that the speaker informs about the important information in Quran and they direct to read Quran.

\section{Complain}

Complain is express dissatisfaction or annoyance about something. This expression is described by the utterance such as :

\section{Perlocutionary Act:}

I said to one of the brothers 'what's your opinion on the matter? Why don't you give your opinion?",

$\rightarrow$ It means that the speaker complains about something that is no reason.

\section{Grateful}

Grateful is feeling or showing an appreciation of kindness; thankful or received or experienced with gratitude; welcome. Here is the utterance.

Locutionary Act:

Alhamdulillah ever since then I look as good as I do now.

$\rightarrow$ It means that the speaker grateful on what he feels.

\section{Persuade}

Persuade is act to cause someone to do something through reasoning or argument. Here is the utterance.

Perlocutionary Act:

Sure, Islam is a good religion, so make me a better person.

$\rightarrow$ It means that utterance persuade someone that Islam is a good religion.

\section{Suggest}

Suggest is to say that (someone or something) is good or deserves to be chosen. Here is the utterance.

Perlocutionary Act :

And they seemed to be living one with the world and that's what really appealed to me.

$\rightarrow$ It means that the speaker suggested by what he has seen. 
Admit

Admit is to agree that something is true. Here is the utterance.

\section{Perlocutionary Act:}

But, they realized that this religion was actually making me a better person.

$\rightarrow$ It means that this utterance explain that Islam gives a positive influence.

After analyzing speech act in video script of Lampu Islam You Tube Channel entitled An Atheist Converting To Islam, the finding can be presented as the followings:

Table 2. Percentage of Classification of Speech Act found in the Video Script

\begin{tabular}{|l|l|c|c|}
\hline No. & $\begin{array}{c}\text { Classification of } \\
\text { Speech Act }\end{array}$ & $\begin{array}{c}\text { Number of } \\
\text { Utterance }\end{array}$ & Percentage \\
\hline 1. & Locutionary & 4 & $25 \%$ \\
\hline 2. & Illocutionary & 2 & $12.5 \%$ \\
\hline 3. & Perlocutionary & 10 & $62.5 \%$ \\
\hline & Total & 16 & $100 \%$ \\
\hline
\end{tabular}

In classification of speech act according to J.L.Austin, perlocutionary act is the most influential utterance which convey moral value about Islam in this research such as 'Sure, Islam is a good religion, so make me a better person."' From the analysis above, there are some expressions of illocutionary act that convey the purpose or the important information, such as 'The fact that we have this world, the fact there is this creation, these are the signs for all of us." In classification of Illocutionary Act, there are some utterances that dominated by expressive. It shows that some utterances express the psychological statement from the speaker about his religious journey such as " $I$ thought Subhanallah look at this religion, look at how strongly are!'”.

\section{Conclusion}

Based on the analysis of Speech Act Viewed From Lampu Islam You Tube Channel entitled An Atheist Converting To Islam, it can be concluded that Speech Act is an important thing to make understanding about the utterance through the expression or action. All the classification of speech act occur in the video script with sixteen occurrences. The most dominant utterance is perlocutionary act. It can be concluded that the script is meant to give offering to the listeners of the video.

Every utterance has the certain meaning or the certain purpose such as to inform. Utterance can be followed as action as well that can effect the hearer. Speech Act is a part of linguistics which uses language in every utterance; while, the language is the most important aspect in social life or interaction. Therefore, speech act helps people to make conversation clearly. Speech Act has classifications that can make it easier for the hearer to determine the meaning of the utterance conveyed by the speaker.

\section{References}

Aitchison, J. (2003). Teach Yourself: linguistics. London: Hodder and Stoughton Ltd.

Austin, J.L. (1962). How to Do Things with words. Cambridge: Harvard University Press.

Bach, K. and Harnish, R. M. (1979). Linguistic Communication and Speech Acts, Cambridge: MIT Press.

Birner, Betty J. (2013). Introduction to Pragmatics. Southern Gate: John Wiley \& Sons Ltd. 
Speech Acts in The Video Script of An Atheist Converting to Islam by Lampu Islam Youtube Channel, Amelia Balqis Siregar, Efendi Barus

Cutting, J. (2002). Pragmatics and Discourse: A Resource Book for Students. London: Routledge.

Halliday \& Hasan. (1976). Cohesion in English. London: Longman.

Holmes, J. (2001). An introduction to Sociolinguistics. London: Longman.

Hufford, J \& Heasley, G. (1983). Semantics: A Course Book. Cambridge: Cambridge University Press

Leech, G.N. (1983). Principles of Pragmatics. London: Longman.

Youtube. (2021). Lampu Islam. Youtube: https://www.youtube.com/channel/UCeTUCqbWph7YQVn9Jf4SuFQ

Searle, J. R. (1979). Expression and Meaning: Studies in the Theory of Speech Acts. Cambridge: Cambridge University Press.

Shank, G. (2002). Qualitative Research. A Personal Skills Approach. New Jersey: Merril Prentice Hall.

Tsui, A.B.M. (1994). English Conversation. Oxford: Oxford University Press.

Yule, George. (1996). Pragmatics. Oxford: Oxford University Press. 